\title{
Transnational Trajectories and Cultural Identity: Lessons from the Chilean-Australian Experience
}

\section{Philippa Collin, University of Technology Sydney}

This paper raises questions about the development of cultural identity as it transforms and impacts upon processes of regional integration in the Asia Pacific Rim, through a consideration of the postnational tendencies created by transnational migrant populations. It focuses on an investigation into the responses of some ChileanAustralians to issues of national identity and the current discourses on immigration, refugees and border protection, I have sought to move debates around immigrant identity in Australia beyond the national. In employing theoretical frameworks from migration theory, namely diaspora and transnational studies, I critically engage with the ways in which Australian identity is discussed in relation to, and by, migrants. These dialogues are then considered in the context of the creation of state-led transnational institutions in order to understand the relationships of power that might impact on transnational projects.

Despite contemporary debate on the decline of the nation state there is good reason for perceived national groups to maintain a vested interest in their home state, and for the state, in return, to pursue at least a paltry relationship with the nations that live within the boundaries of its territory. The volatile relationship between the state and nations is exemplified in the recent conflicts in the former Yugoslavia, Zimbabwe and Aceh. The concept of nation is both a fragile and yet potent idea that operates along trajectories that are both unifying and dividing, that are productive and destructive, and which have a profound impact on all peoples occupying the globe in the so-called postcolonial era. The colonial projects of old have been conquered by the new wave of imperialist global capitalism and this in turn has produced the conditions in which regional integration has become the postmodern economic and political catch phrase. This is particularly evident in the economic and 'defense' alliances that have been formed over the last century, such as NAFTA, NATO, ASEAN and the EU.

The impact of technology, the economic, cultural and political relationships between states and their expatriate communities and the ease of movement between countries 
(which some groups enjoy) have changed the way we position ourselves in the world. Individuals and groups may simultaneously imagine themselves as residents of a global village, as members of communities who may have no physical sited-ness or as independent stakeholders in several different communities whose physical locations and perceived characteristics are distinct and mutually exclusive. This demonstrates the seemingly arbitrary regulation of physical space, whilst allowing conceptual spaces (those that facilitate the passage of information and images) to virtually exist without controls.

Yet, at the same time as we are witnessing a period in which there is apparently greater freedom of movement, we see an international hysteria around border control emerging, particularly in the EU, United States of America and Australia. Refugees and so-called illegal migrants has created a debate on who should be able to enter and exit countries and how. This is despite the fact that there were fewer refugees in 2001 (12 million globally) than ten years earlier in 1991 (16.8 million) (UNHCR, 'Basic Facts'). Nevertheless, state control of borders in the 'minority' world or the 'North' are becoming more stringent, whilst there appears to be a simultaneous departure or fragmenting of the concept of the 'national', as people, images, objects and ideas travel to and from different parts of the globe with varying degrees of regulation. (For instance, the movement of people is highly regulated in some areas whilst the transfer of products or images is hardly regulated at all.)

However, in the context of these 'global' conditions, the challenges are not felt equally across all groups. The challenges that have been made to the status of the 'nation' by technology do not necessarily affect all people equally. For example, Australian Aboriginal peoples may be more concerned about the continuing erosion of their cultural heritage as a result of the persistent forces of neo-colonialism than they are about North American Cultural imperialism (Appadurai 1996a, 32). By the same token, immigrants may find that the pressures to assimilate in their host country can be subverted through the forging of online communities that exist outside the realm of the state. What forms might these communities take, particularly in relation to broader projects of regional integration? How are they given expression and by what means can we observe, participate in or understand them? 
Arjun Appadurai has also argued that in order to fully comprehend the way in which humans organise, express themselves and develop in societies, we should now 'think ourselves beyond the nation' (Appadurai 1996b, 40). This paper is similarly concerned with how the concept of national identity is being challenged in a postcolonial global order that is punctuated by the neo-imperialistic mechanisms of free-market neo-liberalism and the increasing advances of technology in communications, travel and exchange.

The concepts of nationalism and the nation operate on several key levels. In general, the notion of a community defined by 'ethnicity' is considered essential because it symbolizes the common myths, rituals, values, objectives and traditions that unify individuals and groups. This ethnicity is then sited and bound in a physical location from which it may articulate its national identity in comparison with foreign nationalisms. This is what Appadurai refers to as the 'production of locality' (Appadurai 1996b, 42). The projection of 'locality' into non-sited spaces, by way of movement and technology produces interesting challenges for the successful operation of nationalism. Localities are no longer dependent on space. They traverse space by way of technological advances and in the portable imaginations of migrants. These new localities have created a crisis for the modern state and have rendered the concept of the nation most problematic. More importantly they have opened up real possibilities for transnational identities to challenge the remnants of colonial power structures that shelter behind the faltering shadow of the nation-state. This perspective reveals conditions in which alternative political and economic structures might evolve that more equitably reflect the cultural conditions of societies. In particular this perspective offers an alternative to official policies of multiculturalism, which have historically been most vigorously (though differently) pursued by the governments of Australia and the United States of America. This thinking now appears to reveal some of the serious fractures emerging in contemporary nationalist projects.

What does multiculturalism really signify and why is it worthwhile searching for alternative ways to theorise cultural and 'national' identity where more than one ethnic group is a participant? The doctrine of multiculturalism has been heavily criticised in Australia by 'ethnic communities’ who feel they have been commodified and turned into a spectacle, whilst the inherited British culture has been naturalized as 
the core culture of Australian society (Stratton 2000, 23). Multiculturalism has also been trashed by the Howard Government's anti-political correctness stance in an effort to 'prevent the nation from fragmenting', on the grounds that multiculturalism focuses on the things that divide us, rather than unite us (106). Undoubtedly the policy of multiculturalism has a reputation for having made a contribution to the perception of Australian society as a pluralistic and largely 'tolerant' society. However, the shortfalls of the policy of multiculturalism have been criticized most notably because, in the words of Jon Stratton, 'official multiculturalism is formulated around stable that is fixed and unchanging - national cultures' (206). These consumable 'spectacles' are therefore stripped of claims to agency and operate in a core-periphery relationship with the 'White Anglo-Celtic' tradition (Hage 1998). However, this perspective, I will argue, ignores the transnational influences and the referential processes in which countries, such as Australia, are engaged with both the notion of 'home and 'host' countries, (as also applies to British Australians [Stratton, 2000]) and the idea of Australia's place within the 'regional' and 'global'.

This paper departs slightly from the disciplines of sociology, anthropology, geography and political science, that traditionally contribute to the field of migration studies (Vertovec 2001, 3). I take a cultural studies approach that is evocative, rather than purely analytical as I attempt to offer grounding for the directions that a closer, more comprehensive and in depth study might take. In pursuing this objective I therefore propose three points of departure for the study of immigrant responses to the notion of national identity.

Firstly, immigrant identities are framed by the postcolonial conditions that have propelled their migration. Therefore, personal and collective experiences and reasons for immigrating to Australia are profoundly implicated in the development of a sense of Australian identity over time. This must be located within the structural, political and economic social conditions of being a migrant in Australia, and a member of a community whose roots are still connected (if only symbolically) to a foreign birthplace. This assumption builds on the arguments forwarded by Appadurai (1996a \& b), Bhabha (1990; 1994) and Hall (1990; 1992; 1996) in relation to diaspora and identity. Secondly, these identities are constantly engaged with and implicated in the struggle by the dominant national identity to retain control of the national imagination 
(as has been discussed by Stratton [1998; 2000] and Hage [1998]) and these are dynamics which are powerfully felt within regional dialogues, specifically in relation to migration and development. Thirdly, we must consider the impact of transnational institutions introduced from above on transnational populations, for instance, $L a$ Region Catorce and the Cabildos Culturales, in the case of Chilean-Australians.

These propositions are considered in relation to responses of Chileans to the issue of immigration and their reflections on their own Chilean-Australian identity. It is also discussed within the context of La Region Catorce, an initiative of the Chilean Government to creating formal and institutional links between the Chilean State and the Chilean expatriate community.

\section{Searching for new views: Identity, migration and the national subject- positionality and potentiality}

From a theoretical point of view, this paper is concerned with ideas of agency and subjectivity as fundamental to the development of an identity. The paper considers the proposition that if subjectivity and agency are fundamental elements of a 'national' identity, then migrant identities must be, by virtue of their passage through time, place and event, transnational. Therefore, in a country such as Australia, which is comprised of a large immigrant population, a new focus on the transnational nature of these identities signifies the possibility of a postnational conception of Australian-ness. This paper explores this notion as it is experienced by the little-documented Chilean 'community' in Australia with regards to their experience of 'being' Australian. This exploration of identity critically engages with theories of identity, particularly that which is described by Laclau as the 'articulated' postmodern identity (Laclau 1990, cited in Hall, 1992, 278-279). Employing this framework I seek to interrogate notions of national identity, particularly as it is understood and theorized in the Australian context, focusing on the production of identity in immigrants. The point of departure is postcolonialism and the journey is navigated through the theoretical field of cultural studies, utilizing the work of diaspora studies and transnational studies, particularly drawing on Basch et.al. (1994), Appadurai (1996a \& b), Bhabha (1990; 1994), Hall (1990; 1992; 1996), Spivak (1988; 1990) and Vertovec (1999; 2001). 
What is meant when we evoke the notion of 'culture' in discussing national—or postnational-identities? Some argue for the reconceptualisation of culture in terms of fluidity, encounter and disruption in a multidimensional and multidirectional flow across space and time (Appadurai 1996; Bhabha 1994; Gupta \& Ferguson 1992). This is a flow, suggest Gupta and Ferguson, that not only traverses the postcolonial boundaries of modern nation-states, but that exists within the formal borders of these states - though these may be subverted by margin dwellers. These then become borders that are blurred and are transgressed as geographical limits or conventions from 'within'. At the same time, they are challenged by individuals or groups who reside outside the state borders of their 'nation' as exiles, immigrants, refugees and expatriates (Gupta \& Ferguson, 1992, 7). This idea has particular resonance when considering what a regional cultural identity might be and how it would develop.

Appadurai argues that identities travel across and exist in a multitude of dimensionsor 'scapes' — that create the junctions — and disjunctions — between 'economy, culture, and politics' that destabilise the concept of the 'national' (Appadurai, 1996a). Therefore, the postmodern identity must be understood with recourse to influences and events that are peculiar to experience through time and space as it is simultaneously engaging with the rhetoric of the nation. The migrant traverses, intersects and subverts the boundaries of the modern nation-state, through physical movement and the portability of ideas, and in doing so 'acts out' multiple cultural and hence national identities across time and space. What I will also consider is the way that 'difference' is viewed through the lens of culture, and how difference and similarity are constructed in the formation of transnational identities, particularly as they engage with and impact on notions of inclusion and exclusion, and 'the national'.

\section{Traversing the field...who, why and how?}

I advocate the recognition of not one, but many socio-ethno-political centres in Australia. The objective of this theoretical shift is to promote the generative transfers of experience, feeling and knowledge, as opposed to the powerplay between subjects for 'voice' or 'ear'. This acknowledges the line of thinking promoted by Stuart Hall, that identity is fluid and unsettling. In discussing diaspora identities he suggests that they can be seen as 'framed' by two operative vectors: one of similarity and continuity; the other of difference and rupture. More generally, he suggests that the 
narrative of displacement and difference impacts profoundly on certain immigrant subjects, while they simultaneously reach for that which is familiar and constant (Hall 1990, 226, 236). Furthermore, as James Clifford explains, [t]hey are deployed in transnational networks built from multiple attachments, and they encode practices of accommodation with, as well as resistance to, host countries and their norms'(Clifford 1994, 307). Considering the positions of Bhabha and Gilroy on nationalism and identity, it is the performative transgression, the transformations generated by encounters between two or more 'cultures', that produce dialogues about the 'national' and contribute to the construction of (but are not constitutive of) identity.

Investigation of the experiences of migrants who have made the physical and emotional journeys must also consider the histories and social realities that shape the expatriate experience of new structures and relationships of domination. I propose that in the Australian context, these negotiations occur within many spaces, some within the realm of the 'dominant' identity, others in transnational spaces peculiar to particular groups. This paper also draws attention to the way that certain groups create alternative spaces in an attempt to make sense of the identity politics at play, specifically in the context of Australia. This has a direct bearing on how different groups, particularly those identified as 'ethnic communities', interact with and articulate notions of home and host national identities. As Appadurai demonstrates, spheres of meaning are no longer confined to the margins of global discourse. They now operate within localized, globalized and transnationalized spaces (Appadurai 1996a, 10). In this sense they not only respond to and reinterpret sites of immigration, but also influence and engage with localized and diversified cultures in transformative ways. I suggest that the struggle to be both in and between 'places' operates on the identity of immigrants through the experience of migration as they 'arrive from somewhere else' and that this in turn transforms the local, often naturalized, (though not indigenous) cultures. These multiple influences occur because the rhetoric in Australia is simultaneously one that promotes a 'multicultural' society, recognizing the diverse influences on the nascent Australian culture and yet, it is also a discourse that is uncertain about how it defines membership to the Australian 'type'. ${ }^{1}$ Australian

\footnotetext{
${ }^{1}$ Australian 'type' in this sense evokes images and stereotypes promoted as specifically NOT ethnic, NESB, migrant Australians. This draws from the way in which Stratton uses the notion of an 'Australian type' in his book, Race Daze (1998).
} 
identity is not yet able or willing to remove the explanatory hyphen between that place one is 'from' and the place one is 'at' (Gilroy, 1991). This is because the simplistic use of the hyphen in, for instance 'Chilean-Australian', draws attention to what is missing — or required — for unconditional membership, whilst simultaneously emphasizing the 'ethnically' defined cultural differences as sites of resistance to the national type (Gilroy 1991, 281). In the Australian context, this forms a paradox that works on immigrants as they are positioned as 'ethnic' subjects. Their 'ethnicity' is rhetorically referred to as contributing to the 'diversity' of the Australian community, (What it means to be an Australian Citizen, DIMA 1997) and yet, it is often viewed as signifying resistance to 'traditional' notions of Australian-ness (Smith \& Phillips 2001). Hence, my interest lies in the ways in which this relationship is negotiated and 'where' or 'how' identity-constitutive dialogues emerge in those who traverse these shifting, incongruent and yet overlapping spaces.

During 2002 I conducted interviews with Chilean-Australians in Sydney. These interviews sought to explore the responses of Chilean-Australians to questions about national identity, place and home. Subjects were also asked to comment on the current refugee and immigration policies as a way of thinking about how transnational identities interpret and engage with notions of belonging, membership and place.

\section{Roots of the Chilean community in Australia}

There have essentially been four 'waves' of migration from Chile to Australia. The first occurred in the 1960s following industrialization, amidst continuous political conflict and increasingly unstable economies across the region. Chileans who arrived in Australia at this time immigrated at the end of the post 1945 boom in the wake of the White Australia Policy. The second wave came in the years around 1970, in the lead-up to and as a response to the election of the socialist Government headed by Salvador Allende. These Chileans were largely from the political right, fleeing what they feared would be a radical socialist regime. The third influx of migrants came after the 1973 military coup. These immigrants were fleeing into exile, escaping political persecution, torture and execution. The fourth wave may be considered as still 'coming in'. It includes those who have arrived as participants in the Family Reunion Program and those who have immigrated independently to Australia following a period of steady economic growth and political stability in Chile. The 
greatest number of Chileans arrived in Australia during this period from 1973 to 1989; around 9,000 came between 1973 and 1978 and similar numbers arriving between 1984 and 1989 (1991 Census). ${ }^{2}$ Chileans who arrived in Australia during this period found Australia a generally welcoming place (Caba 1988, 18-19). At the end of 2000, the Department of Immigration found that there were 33,838 Chileans residing in Australia (http://www.immi.gov.au/statistics/ infosummary/source.htm).

The 'everyday struggles' of adjusting to life in a new country were matched by a direct and organized campaign during the 1970s and 1980s by many Chileans in Australia opposing the Pinochet dictatorship (Martin Montenegro 1994, 44-46). The participation of Chileans in formal politics, allied with Australian trade unions, established a strong organizational tradition of bringing together Chilean-Australians for political, cultural and social activities. Chilean history and culture are also 'kept alive', re-articulated and experienced in Australia by various interest groups. Beyond organized modes of cultural expression, Chilean culture is increasingly consumed on a daily basis by way of technological advances. The internet and cable television have reduced economic barriers to purchasing satellite television taking the consumer beyond the filtered information of the Spanish-language media and Esta Semana, a program made especially for Chileans living outside Chile. Therefore, Chileans-and their Australian-born children-are able to experience being Chilean through the direct consumption, not only of Chilean news and events, but also of popular culture.

However, for some Chileans, their arrival in Australia as political refugees is a particular point of reference in the process of developing a sense of Australian-ness. In the Australian context the migrant, particularly the refugee, has been awarded status of the 'most' Other, what Ashish Nandy describes as the 'intimate enemy' in colonial times (Papastergiadis 1997, 267). Many Chileans came to Australia as political asylum seekers and their experience of being (in) Australia is connected to the stigma of being a refugee.

\footnotetext{
${ }^{2}$ It is not my concern here to analyse what these figures might reflect in terms of changes to government policy. But it would be interesting at another time to investigate how changes in government policy have affected the arrival of migrants from South America.
} 
All of the Chilean community that came over as refugees understand how hard it is, after what you have been through, then arriving in a new country, where you can't speak the language, or find a job in your field (interview a).

Therefore I would like to consider three sets of circumstances that affect the ways in which Chileans have engaged with the process of identity formation in Australia. Firstly, how does the immigrant engage with his/her own construction of the 'other' in relation to notions of Australian identity, particularly as defined by multiculturalism and especially in Prime Minister John Howard’s present post-multicultural age? Secondly, how are Chileans' notions of Chilean-ness disrupted or contested from 'within'? And thirdly, to what extent are these negotiations affected by the movement and transfer of the immigrant subject across increasingly globalized times and spaces? As Papastergiadis observes, 'the arrival of a foreign text is never a perfect isomorph of another culture; it too, is formed by the travails of travelling' (Papstergiadis1997, 272). This process is described by Fiedler:

I try to put together my own self ravaged by the separation of those two hemispheres I happen endlessly to move between without ever leaving, without ever returning, without ever arriving. I am Deluzean, I am experiencing the smoothness of the global. (Fiedler 2000, 42)

This process crosses over into the 'territory' of the 'Australian' and disrupts the dominant myths, images and ideologies of Australia and her struggle to come to terms with the presence of the 'ethnic' other.

The subscription to a particular identity politics is the active and conscious exercising of agency and a deliberate positioning of subjectivity on the part of each individual or group. It cannot be assumed that assimilation to a new 'national' type is the inevitable and invariable outcome of immigration. On the contrary, it suggests that it is possible to subscribe to more than one identity at a time. This perspective is particularly useful when considering how identity studies can push postcolonial theory into a consideration of the postnational by focusing on the challenges posed to nationalism by migrants.

As Hall notes, there are several main, but not exhaustive, elements that constitute traditional notions of nationalism. These include an emphasis on a commonly accepted and valued narrative that emphasizes 'origin, continuity, tradition and timelessness'(Hall 1992, 294). Logically, this definition suggests that members of a 
nation assume the unique characteristics of the commonly accepted and valued narrative defined by Hall. There are obvious problems with this conceptualization of nationalism. However, the inconsistencies, contradictions and inventions are precisely the factors that allow us to theorize more accurate representations of identity. What is particularly well illuminated by the diversity of Chilean-Australians, is that the challenges produced by attempting to theorize national identity, might well be best understood by theorizing beyond the 'national'. Indeed, alternative terminology most frequently used to describe migrant groups, such as diaspora or cosmopolitan, are simply inadequate for describing the ways in which migrants conceptualize their identity in relation to the doctrines of nationalism. For example it is difficult to speak with any great clarity of a Chilean 'diaspora' given the breadth in experience and conceptualization of Chilean and Chilean-Australian identity. However, regardless of these differences, most Chileans will go to great lengths to defend their 'Australianness' just as they will vigorously and proudly demonstrate their 'Chilean-ness'.

\section{Perceptions of 'identity' in the Australian context}

Any formation of immigrant identity is implicitly affected by the dynamics of the discourse of national identity within the host country. Thus, the development of a regional identity, as would form through the strengthening processes of regional integration, would also be influenced by the discourses of competing nationalisms as they engage with each other in the regional space. This must cautiously avoid the centralizing or naturalizing of any one cultural group, as was the legacy of the colonial era.

As Stratton has observed, Australian identity has always been bound up in the idea of a 'racially based Australian type'. Australian-ness has always been defined against what has been considered to be 'Un-Australian'. Indeed race has operated here as '.... a marker to exclude those who were not considered to be eligible to be members of the nation'(Stratton 1998, 9). Despite the advances made since the end of the White Australia policy, and the gains made by the practice of official multiculturalism during the 1980s and early 1990s, race and ethnicity are still key determinates in the perception of 'Australian-ness'. The major criticism, or failing, of multiculturalism is well debated and Bhabha puts it simply when he says that the '...universalism that paradoxically permits diversity masks ethnocentric norms, values and interests' (in 
Rutherford 1990, 208). To be more precise, what is referred to as 'ethnicity' might be better understood as signifying a set of behaviours characteristic of or associated with a non-Anglo culture. Therefore, 'difference' is the most prominent characteristic of what is referred to as ethnicity. This difference is linked in racist discourses in Australia to the notion of the 'anti-national' or 'un-Australian'.

In a recent study on notions of 'un-Australian', respondents ${ }^{3}$ said that group behaviour that reflected placing foreign influences or loyalties above those of Australia, or 'ethnic separatism', was seen as an affront to Australian values and norms of civility (Smith \& Philips 2001, 12). Whilst overtly racist attitudes, such as those presented by Pauline Hanson were also held to be 'un-Australian', the beliefs expressed by Hanson were similarly reflected in the view that by '... allegedly remaining in ghettos, neglecting to learn English and failing to assimilate, certain minorities were perceived to be separatist, thumbing their noses at other Australians' (Smith \& Philips 2001, 12). This focus on the perceived resistance of immigrants to the prescribed Australian identity is seen by Hage as a challenge to the 'fantasy of white supremacy' (Hage 1998, 209). The implicit contradictions in the way in which nationalism is evoked in the Australian context reveal the racist undertones of both the nationalist and the multicultural projects. Essentially this has created a potent confusion in the Australian psyche, affecting new immigrants as profoundly as it affects the later generations of the colonial society. Several responses to my questions about how people viewed their own national identity were also caught-up in the contradictions exposed by Hage's critique of the 'myth of white supremacy'. These Chilean-Australians defined belonging to, or involvement in, a multicultural community as the essence of being Australian. Difference as well as collective efforts to 'contribute to the development of society' was what gave one participant a sense of national identity and most participants also recognized that ethnic difference affected their entrance into the national discourse, but that this was achieved through a sense of participation and community:

I feel very much a part of this society. I live in this area and I feel more a part of the multicultural society of Australia. Because in my view I see Australian society, not as an AngloSaxon society, I see Australian society as a multicultural society. So that helps me to feel that I am part of this society and I feel that I am part of the development of this society that more and

\footnotetext{
${ }^{3}$ Respondents included people from non-Anglo backgrounds.
} 
more is becoming into a multicultural society...It's not like I forced myself to become part of it. But over the years I became part of it. That's helped me a lot. The way that I see others, the way that I function within society because I feel part of something (interview b).

Therefore the contradictions also reinforce the divisions. The focus on difference, so greatly valued in the discourse of multiculturalism denies the 'ethnic' subject full membership to the traditionally defined Australian national subject. However, transnational identities are able to subvert the self-appointed authority of nationalist discourse by creating alternative spaces that have greater perceived value than the 'national'. For instance, the 'local' community is seen as a microcosm of society, while the transnational spaces are what contain the greater 'community'. This suggests that whilst theories around hybridity and Hage's reading of the dynamics of multicultural identity in relation to a white core are imperative to a comprehensive reading, they are not authoritative or exhaustive. The articulated identities of migrants suggest that whilst transnational identities are affected by essentially racist discourses of assimilation, integration and multiculturalism, they are also able to disengage from these identity spaces and create and interact with identity spaces that are evoked under different sets of conditions. It is within this same conceptual space that the notion of a regional identity, located in the exchange and valuing of diverse cultures, can be generated-where the real and imagined boundaries of the nation have been ruptured.

This contributes to the on-going negotiation of self-identity. Several people who were interviewed pointed out that they will never be able to 'not be Chilean. That is where I was born. That is who I was' (interview a). And yet, they stressed the fact that having lived in Australia for fifteen or twenty years, their community, their lives have been made in Australia, and it is equally impossible in this sense not to feel 'Australian' too. One particular participant noted that, by virtue of her highly traumatic experiences and subsequent departure from Chile, she felt she 'owed' a lot to Australia, and that this gratitude formed the basis of her loyalty and identification as part of the Australian community (interview e). Hage observes that non-Anglo immigrants to Australia have consistently found that (the extent of) their 'Australianness' is continuously being called into question, that they must 'prove' that they are just as Australian as any Anglo-Australian (Hage 1998, 218-219). This suggests that the non-Anglo subject is constantly referring back to a 'white' centre to measure their relative closeness or distance from this 'desired' model. However, at the same time, 
they express an identity that is not represented within the historical imaginary of the Australian nation. This reflects self-referencing to and the active recreation of a foreign past and present, further evidence of active identification with a transnational identity. For several interlocutors, this is manifest in their experiences of return to Chile and being confronted by a reality that did not fit their imagined place.

So the first time I went back I am sitting there trying to be normal, trying to be myself, after 18 years, trying to be one of them, blah, blah. And I thought about my freedom there, and I observed people and how they act. And I was shocked. Because, in my days, in my days there to 1975 ...you talked to people around, you started a conversation with the person sitting next to you. There was some kind of conversation or inter-relation to, actually even on the micro. ${ }^{4}$ But now there is nothing. And that was the first indication for me that things have changed (interview b).

Simultaneously, the process of struggling with the notion of what is or was Chilean in them helps them to form an understanding of their own 'Australian-ness'. I argue that this is particularly challenging to the broader discourse of Hage's great 'white myth' because it demonstrates that immigrants do not construct their identity only in response to a 'white' core culture. Rather, their experiences of migration and return, of negotiating the changes in their 'indigenous' sense of identity provides an equally powerful point of reference. In the words of Papastergiadis:

Identity politics is born from the realisation that certain social and historical circumstances have effectively marginalised or negated the representation of their identity: the primary struggle is against self-negation. To reclaim, or to invent an identity that was previously prohibited, is a confrontation with the structures of power that privileged one form of identity over all others. It is this process of rethinking the relationship between the personal and the political that is disturbing. It introduces an awareness of the way identity is always a performative process and how identity is constructed across difference. It highlights the role of institutions for the establishment of roles and functions that affirm certain forms of identity (Papastergiadis 1998, 31).

What emerges for Chilean-Australians is a propensity for self-reflective examination of their identity as it emerges somewhere between the 'home' and the 'host'. For Chileans-Australians there is the recognition that they engage with 'separate' identities. These identities are essentially transnational ones created because of the need, and the ability, to imagine identities that are not confined by the boundaries of the nation state (Vertovec 2001, 1). In the case of Chile, these different identities are composed with specific political and historical points of reference. Most importantly, these points of reference vary dramatically depending on the individual stories of 
Chilean immigrants. I suggest that this negotiating of transnational identities, the process of revising and refining, articulating and de-articulating identity signifiers, directly informs the dialectics of the Australian identity 'crisis' described by Lattas (Lattas 1990, 54 cited in O’Reagan 1996; 319). Therefore the Australian identity is also responding to the increasing extension of the third space in the process of continuing globalisation (Pieterse cited in Mandaville 2001, 98). There is another factor in the specific case of Chilean-Australians that complicates these two perspectives. The production of their transnational identity has arisen due to, specific but varying, historical and political conditions. This is simultaneously positioned in conflict with the dominant identity of the host country, one that is definitively based on the exclusion of difference (Hassan 1998, 28). Therefore Chilean-Australians are in a constant process of 'playing out' different articulated identities that 'travel' across the scapes described by Appadurai in response to notions of difference (Appadurai 1996a, chapter 2.) It is possible that these identities may take different forms when engaging in regional spaces. When is one a Chilean or an Australian in a regional dialogue? How can we avoid the need to hyphenate the migrant identity? Is the separation of the immigrant identity into two-past/present, home/host-inevitable, or is it a response to the structures that organise and control cultural interactions?

This idea has particular resonance when considered within the context of the current debate over refugees. This point was emphasised by one interviewee who stated that while she could never forget why she came to Australia, and what she went through, she did not feel, although she wanted to, as though she was free of the stigma of 'refugee' (interview e). Another felt that by denying recognition of the positive contribution that refugees have made to the Australian community, the dominant discourse was really denying them full ‘membership’ as Australian:

Well, yes, every individual has different experiences, but sometimes when you meet, when you speak about the issues of refugees there is a lot of sadness, you know 'I had such a bad time'. Yeah, well okay we had that but, I say, well it is time for us to celebrate our contribution to the development of this society. Yeah, we have to say that we suffered, we have to tell people our experiences. We have to tell that it is horrible to leave everything that you have and just go, to be tortured or traumatized, it's awful. But we have to highlight that yeah, also we have contributed to this society. You see there are many, many refugees in Fairfield and you find them in all areas, so its time for us to celebrate our contribution to this society, to the City of Fairfield (interview b).

\footnotetext{
${ }^{4}$ Local public buses.
} 


\section{The travelling subject: engaging with space, the state and society}

To a certain degree the ways in which migrant identities are articulated (Hall, discussed by Daryl Slack 1996, 115) are the ways in which they imagine, interact with and pass through national and transnational spaces. The roles of institutions, particularly those that represent the state, have a profound impact on the processes and forms of articulation in migrant identities. What will be particularly interesting in the next few years is the way that the Chilean community engages with the La Region Catorce and the Cabildos Culturales, both formal initiatives of the Chilean Government.

La Region Catorce-The Fourteenth Region—and the Cabildos Culturales, or 'Cultural Councils', are both initiatives sponsored by the Chilean Government. Whilst they both have transnational trajectories and contribute to an overall trend towards top-down transnationalism, they have slightly different objectives. The Region Catorce has emerged as a way by which the Chilean Government can enter into dialogue with the expatriate community, emphasising a reunion between the Chilean state and those Chileans living outside the physical boundaries of Chile. Whilst considered by many to be fundamentally rhetorical at this stage, the potential benefits both for the expatriate community and the state are considered to be significant, particularly by the government officials (Spanish Herald 2002, 4). The Cabildos Culturales were developed through a process of consultation with Chilean people on the issue of culture and how the Government should be supporting the internal and external development of and expression of Chilean culture. It is a project that began in Chile, but will also be executed through the Chilean consulates in countries that have significant expatriate communities including Switzerland, Argentina and Australia (Corthorn 2002, 17). Despite having different objectives, the Cabildos and the Region Catorce have to a certain degree been confused in the minds of some ChileanAustralians.

The first conference of the Sydney Cabildo Cultural was conducted on the $25^{\text {th }}$ and $26^{\text {th }}$ of April, 2002. It was attended by members of the public, invited Chilean interest 
groups and the Chilean Minister of Foreign Relations and the Minister of Education. ${ }^{5}$ In bringing together diverse sectors of the Chilean community many issues were raised, ranging from interpersonal gripes to those regarding education and exchange programs, youth issues and specific concerns relating to the artistic, literary and communications-based communities. However, there was also a contingent of individuals and groups who felt that the Cabildos should also address the long unanswered socio-political needs of the expatriate communities who had lived in ' $e l$ exterior $^{6}{ }^{6}$ for so many years. Their objectives also included recovery of Chilean nationality (in order for there to be dual citizenship status) for Chileans who have taken Australian citizenship, voting rights for externally based Chileans, exoneration of political exiles, and the resolution of pension and national service issues for Chileans living in Australia (Cabildos Culturales 2002).

In other words there was a great deal of confusion over the purpose of the Cabildos Culturales. In the words of one delegate:

The thing was that the Cabildos Culturales was meant to cover cultural issues, you know, literature, poetry - there are many wonderful Chilean poets-dance, folklore. But they also took the opportunity to discuss issues that are not related to cultural initiatives, such as the Chilean pensions and dual nationality (interview d).

Because Chileans have never before been presented with the opportunity to engage in direct dialogue with the Chilean state, some felt that it was impossible to discuss 'culture' without addressing the 'political' needs of the community. These relate to Citizenship rights, national identity and cultural and state relations with the Chilean diaspora, which has traditionally been a strong lobby in favour of political reform, for instance the pro-independence movement during the dictatorship and the campaign for the prosecution of General Pinochet (Martin Montenegro 1994).

Despite the confusion, the sudden interest of the Chilean Government in recovering direct links with the expatriate community has come partly through the recommendations of consultative groups in the (Chilean) community. However this process might also be understood as a strategy for better utilising (and controlling) the influential and wealthy expatriate community.

\footnotetext{
${ }^{5}$ Conferences were also held in Melbourne, Canberra and Adelaide.
} 
The Chilean Government is not the first to propose such a project. In 1991 the newly inaugurated President of Haiti, Father Aristide referred to Haitians living overseas (primarily in the U.S.) as the 'Dizyem Depatman-an'—or 'tenth department—Haiti being divided up internally into nine departments (Basch, L.G. et. al. 1994, 1-2). Similarly, India has the category of non-resident Indian (people of Indian origin living outside India), which offers them special rights especially regarding taxation, property rights and freedom of movement in and out of India (Appadurai 1996, 45-46). Clear, though sometimes legally insubstantial, statements are made in attempts to tie expatriate communities to their 'home'. This creation of a symbolic 'tenth state', or, as in the case of Chile, 'fourteenth region', is a deliberate effort on the part of a state to reclaim the transnational space. This space has historically been occupied by the expatriate community that has effectively become a powerful political and economic force. Basch draws our attention to the fact that in most circumstances, the expatriate communities continue to consider themselves to be a part of their home country and culture (Basch et. al. 1994, 146). Therefore, the emigrant population engages with such projects partly because it provides them with an opportunity to engage in meaningful dialogue with the home state over issues pertaining to rights and compensation. It also offers, in some cases, an opportunity to be directly involved in the politics and social and economic development of their country of origin. The Spanish language papers have focused on this function of the Cabildos as a vehicle for dialogue between the state and the expatriate community. According to the $E l$ Nuevo Espanol en Australia, quoting another Chilean bureaucrat:

Explico como ese organismo que esta promoviendo la organization de los grupos comunitarios que se estan agrupando para dar presencia a la Region del Reencuentro, y cuyo proposito es lograr que los chilenos del exterior refuerzen sus vinculos con Chile y se mantengan integrados al pais (Corthorn 2002, 17).

What the Cabildos has demonstrated is that the Australian-Chilean community is deeply divided over the sorts of issues that these consultative bodies should address. To some extent this reflects the political divisions in the community. For instance, in general, people who identify with the political right do not want to engage in discussions relating to compensation issues for victims of the dictatorship. There is a

\footnotetext{
6 'the exterior', or overseas.
} 
strong split within the community between those who feel that institutions such as the Cabildos Culturales must also have a political role, and those want to create a depoliticised cultural project. Leftist Chilean organisations in Australia have a strong tradition in promoting Chilean culture, particularly during the dictatorship, as a way of undermining the violent oppression and injustices practised by the Chilean state (Martin Montenegro 1994, 46). In consideration of the historical divisions along political lines, it is not unexpected to find that what is constructed as 'culture' is politicised by the 'left', whilst it is rendered apolitical, or beyond the political, by the 'right'. Despite these differences of opinion, there are significant issues, such as dual citizenship (currently not recognised by the Chilean Government), that potentially reach beyond the political differences within the community, raising questions about identity for all its members. This draws into question the changing role of the state in relation to the emerging importance of the transnational population (Vertovec 1999, 5).

The split in the Chilean-Australia community complicates a reading of Chilean transnationalism, as the 'community' can hardly be considered a unified group although there was a strong institutional push to promote the Cabildos Culturales as a forum in which all Chileans were welcome to contribute to the debate on what form spaces for dialogue should take (Spanish Herald 2002).

In fact, with regard to the experience of the Cabildo that was held in Sydney, this project of identity (re)formation highlights what Langer identifies as the tension within the "fictive bounds of 'ethnic community"' (Langer 1998, 166). The fictive separation of culture from politics, which Langer argues is implicit in the multicultural project, emerged in the Sydney Cabildo Culturales as a primary point of contention, one which illuminated the debate about what being a Chilean-Australian meant. For some, the Cabildos Culturales were an opportunity for the community to utilize the elements of its 'successful' insertion into Australian society to further 'cultural' projects in Chile and between Chile and Australia. But in the words of one man: 
become really democratic. I can’t be Australian or Chilean, because I don't really have that choice (interview a).

The top down approach of the Cabildos Culturales to extend the democratic reform of Chile to those living in the exterior was seen as a farce by many. According to another man:

The Cabildos are a political project, not a social project. They are about power and the political parties in Chile really just want to use the Chileans living outside of Chile as a way to destabilise the current Chilean Government (interview f).

The efforts of certain members of the community to exclude others was largely based on political differences, and diverging ideas about what the Cabildos Culturales were intended to achieve:

Well, yes, basically there were some people and groups who weren't invited. It was all organized in a bit of a rush and for instance the Mapuche Group - representing the indigenous people of our country, you know, like the Australian Aborigines - they weren't invited. Neither was the group, the Communists. So there were people there, they came anyway, and they started arguing about why this other person was invited and not them, and it became pretty political...(interview d).

The confusion around where the boundaries of the nation are drawn give rise to the need for the development of new State institutions that can reflect and engage with these diversified identities. Participants were largely skeptical about what the Cabildos Culturales had achieved in terms of meaningful dialogue between the Chilean Government and the various groups of Chilean-Australians although, in reflecting on the outcomes of the Cabildos Culturales, all of the participants were positive about the networks that had been formally established between certain sectors of the Australian community and Chilean Government. However, they also recognized that the Cabildos Culturales had only emphasized the divisions between Chilean-Australians along political and historical lines.

Finally, the 'arrival' of the Cabildos Culturales and the Region Catorce by no means reflect an emerging transnationalism in the Chilean community. Conversely, these initiatives arise nearly thirty years after the first semblance of transnationalism emerged (Martin Montenegro 1994, 42). Chileans, particularly those from the political left, and especially those who arrived as refugees, have maintained transnational relationships as theorised by Basch et. al. (1994), Vertovec (1999), 
Itzigsohn (2000), and Webner (2002) since their arrival in the early 1970s. I suggest that the Cabildos Culturales and the Region Catorce represent a new thread in Chilean transnationalism whereby the specifically transnational experiences of Chilean-Australians are being appropriated by the state and assimilated into the concept of the nation. As Itzigsohn points out, it is only really in the very recent past that American and Caribbean States have been engaged in meaningful dialogue with their expatriate communities (Itzigsohn 2000; also explored by Basch et. al. 1994). Therefore, this development signifies a shift on the part of states to recover control, or to redefine the parameters of national identity as they apply to transnational cultures, but does not suggest that communities themselves have not already navigated these borders. Therefore 'official' transnationalism is really about control, and the recapturing of the transnational imagination. At the same time as the hyphen between 'nation-state' is shifting internally, the efforts of the state to control the national identity is extending outside the boundaries of the state, responding to the conditions created by migration and the identity scapes theorised by Appadurai (1996a). This is both prompted and counteracted by the needs and demands of a transnational population unbound by the traditional structures of the state that are producing the conditions for new institutional and state structures.

A concept introduced by Schein that is useful in the analysis of Chilean-Australian identity and the way that they are responding to these events is the concept of 'identity exchanges' (Schein 1998, 300). It helps us to conceptualize the process of redefining transnational identity as reflected in the ways in which Chileans engage with critical political and social issues within Australia. This concept is particularly useful in appraising the Cabildos Culturales and the Region Catorce and the dialogues being generated between Chile and Australia and within the various groups that represent the Chilean-Australian 'community'. Schein employs the term 'identity exchange' to 'describe the multiple agencies that comprise this overall, yet, fragmented project out of which transnationality is being forged' (Schein 1998, 300). Essentially, Chilean-Australian identities emerge out of a process of exchange, between past and present contexts, real and imagined experiences and the relationships that make Chilean and Australian identities meaningful to individuals and groups. This demonstrates the centrality of the transnational to the development 
of Chilean-Australian identity. It challenges the 'core white culture' as the central reference point for the development of identity in Chilean-Australians.

\section{The unstable status of national identity: concluding comments}

Stuart Hall (1990) advocates for the theorization of identity precisely because it enables us to conceptualize new kinds of subjects. Theorizing identity establishes new places 'from which to speak' and, as this paper argues, renders visible the placesoutside the discourse of the national—where dialogues are already being created.

The experience of Chilean-Australians in migrating to Australia, living in Australia and adopting, rejecting, interchanging and recreating identity characteristics which are extracted from experience, memory and imagination, are filtered through discourses of the national, just as they are affected by political and historical events. The formation of identity in Chilean-Australians is equally, if not more so, affected by being in and passing through the transnational spaces between 'home' and 'host', as they are defined by the notion of a core culture, to which the migrant is assumed to assimilate. What this suggests is that the notion of the 'national' is not the central force when it comes to transforming migrant identities. They are not sculptured by the desire to somehow become like all other Australians, but rather, become Australian by way of a variety of connections, processes and engagements which actively and productively extend the notion of the ‘Australian’.

Furthermore, a transnational reading of identity—one that favours transnationalism as the central point of reference for understanding immigrant identities, and thus, the broader Australian identity-directly refers to the 'spaces in between' and the 'process' of cultural and identity transfer. I argue that Australian culture, and hence, Australian identity is being generated in these spaces. This destabilizes the fabricated authority and dominance of the western centre, particularly the fantasy of a cultural core, by focusing on agency and movement as key determinants of identity. This is not to claim that the colonial experience has not produced a powerful legacy with which all postcolonial societies must in some way engage. Rather, I suggest that it is losing its limelight, fading into the wings of a globalized stage now occupied by transnational identities that subvert the borders of the state and that are not controlled by the heavy gaze of the nation. As Ulrick Beck has observed, globalization creates 
the context in which 'sovereign national states are criss-crossed and undermined by transnational actors with varying prospects of power, orientations, identities and networks' (cited in Vertovec 2001, 3). The implications of this proposition are supported by the discussion that I have laid out in this paper. Therefore, I suggest that in the Australian context, transnationalism may be used as a theoretical framework for the development of a postnational conception of Australian identity: an identity whose core characteristics are unbound by fluidity, dynamicism and progressiveness.

The theoretical framework of transnationalism lend itself to projects in regional integration because it directs focus to the importance of creating meaningful and representative regional spaces that reflect the changing nature and role of identity. It emphasizes the ways in which we must make these initiatives more genuine, dynamic and engaging across and between different members of a common region. 


\section{Reference List}

Appadurai, A, 1996a, Modernity at Large: Cultural Dimensions of Globalization, University of Minnesota Press, Minneapolis.

1996b, 'Sovereignty Without Territoriality: Notes for a Postnational Geography’ in, The Geography of Identity, ed. P. Yaeger, University of Michigan, USA.

Basch, L. Schiller, N.G. \& Blanc, C.S. 1994, Nations Unbound: Transnational Projections, Postcolonial Predicaments and Deterritorialized Nation -States, Gordon and Breach, Langhorne, PA.

Bhabha, H. 1990, Nation and Narration, Routledge, London. 1994, The Location of Culture, Routledge, London.

Bureau of Immigration, Multicultural and Population Research, 1991, Community Profiles, 1991 Census, Chile Born, Australian Government Publishing service, ACT.

Caba, G. 1988, Hidden Heritage: The Fairfield Community, Fairfield City Council, Wakely, NSW.

Carta de Sydney, Cabildos Culturales, Sydney 2002.

Clifford, J. 1999, 'Diasporas' in Migration, Diasporas and Transnationalism, (eds) S. Vertovec \& R. Cohen, Edward Elgar Publishing Ltd., Cheltenham.

Corthorn, H. 2002, 'Cabildo Cultural unio a la comunidad chilena', El nuevo Espanol en Australia, Sydney, 30 April, 17

Daryl Slack, J. 1996, 'The Theory and Method of Articulation in Cultural Studies' in Stuart Hall: Critical Dialogues in Cultural Studies, eds David Morley, \& KuanHsing Chen, Routledge, London.

Department of Immigration and Multicultural Affairs 1997, What it means to be an Australian Citizen, Commonwealth Government of Australia.

Department of Immigration and Multicultural Affairs, http://www.immi.gov.au/statistics/ infosummary/source.htm, accessed July 2002.

Fiedler, S. 2000, Beyond Pinochet: Class, Power and Desire in Pinochet's Chile, PhD. Thesis, School of Sociology, University of New South Wales, Sydney.

Gilroy, P. 1991 “'It ain’t where you're from, It's where you're at”...The Dialectics of Diaspora Identification', Third Text 13 Winter, pp.3-16 sourced here in Migration, Diasporas and Transnationalism, eds S. Vertovec, \& R. Cohen 1999, Edward Elgar Pub.Ltd, Cheltenham.

Gupta, A. \& Ferguson, J. 1992, “'Beyond Culture”: Space, Identity and the Politics of Difference', Cultural Anthropology February Vol.7, No.1, pp. 6-23.

Hall, S. 1990, 'Cultural Identity and Diaspora' in Identity: Culture, Community, Difference, ed. Jonathan Rutherford, Lawrence and Wishart, London. 1992, 'The Question of Cultural Identity' in Modernity and its Futures, eds S. Hall, S. D. Held, \& T. McGrew, Polity Press in Assoc. with the Open University, Cambridge. 1996, 'New Ethnicities', in Stuart Hall: Critical Dialogues in Cultural Studies, eds D. Morley \& C. Kuan-Hsing, Routledge, London.

Hage, G. 1998, White Nation: Fantasies of White supremacy in a Multicultural Society, Pluto Press, Sydney. 
Hassan, I. 1998, 'Counterpoints: Nationalism, colonialism, multiculturalism etc. in personal perspective', in Multicultural States: Rethinking Difference and Identity, ed. David Bennett, Routledge, London.

Itzigsohn, J. 2000, 'Immigration and the Boundaries of Citizenship: The Institutions of Immigrant's Political Transnationalism [1]', International Migration Review Winter 2000, v.34, i.4, p.1126.

Langer, B. 1998, 'Globalisation and the Myth of Ethnic Community: Salvadoran Refugees in Multicultural States', in Multicultural States: Rethinking Difference and Identity, ed. David Bennett, Routledge, London.

Mandaville, P. 2001, Transnational Muslim Politics: Re-imagining the Umma, Routledge, London.

Martin Montenegro, G.A. 1994, La Campania de solidaridad de Australia con Chile: 1973 - 1990, M.A. (Honours) thesis, University of New South Wales.

Morely, D. \& Chen, K-H. (eds) 1996, Stuart Hall: Critical Dialogues in Cultural Studies, Routledge, London.

O’Reagan, T. 1996, Australian National Cinema, Routledge, London.

Papastergiadis, N. 1997, 'Tracing Hybridity in Theory' in Debating Cultural Hybridity: Multicultural Identities and the Politics of Anti-Racism, eds P. Webner \& T. Modood, Zed Books, London. 1998, Dialogues in the Diaspora: Essays and Conversations on Cultural Identity, Rivers Oram Press, London \& New York.

Pereira Petruzzi, A. (ed.) 2001, Report of the First National Convention of Chilean Organisations in Australia, Sponsored by Hon. Bob Carr Premier NSW, Fairfield City Council.

Rutherford, J. (ed.) 1990, Identity: Community, Culture, Difference, Lawrence \& Wishart, London.

Schein, L. 1998, 'Forged Transnationality and Operational Cosmopolitanism' in Transnationalism from Below Vol 6, eds M.P. Smith \& L.E. Guarnizo, Transaction Publishers, New Brunswick.

Smith, P. \& Phillips, T. 2001, 'Popular understandings of "UnAustralian”: an investigation of the un-national', Journal of Sociology, Dec 2001, v.37,i.4., p.323(19)

Stratton, J. 1998, Race Daze: Australia in Identity Crisis, Pluto Press, Sydney 2000, 'Not Just Another Multicultural Story', Journal of Australian Studies September, Victorian Historical Association, p.23.

Cristobal Valdes Saenz, Chilean Ambassador to Australia, 'Letter to the Editor', Spanish Herald 23 April 2002,p. 4

Spivak, G.C. 1988, In other Worlds: Essays in Cultural Politics, Routledge, London \& New York

Spivak, G.C. 1990, \& Harasym, S. (ed.) The Post-Colonial Critic: Interviews, Strategies, Dialogues, Routledge, New York

United Nations High Commissioner for Refugees, 'Basic Facts', http://www.unhcr.ch/cgi-

bin/texis/vtx/basics/+cwwBmeLqZw_wwwwMwwwwwwwmFqtFEIfgIhFqoUf IfRZ2ItFqtxw5oq5zFqtFEIfgIAFqoUfIfRZ2IDzmxwwwwwww1FqtFEIfgI/ope ndoc.htm

Vertovec, S. 1999, 'Conceiving and Researching Transnationalism', Ethnic and Racial Studies vol. 22, i., 2, p.447. 2001, 'Transnationalism and Identity', Journal of Ethnic and Migration Studies, Oct. 27(4): 573. 
Werbner, P. 1997, 'Introduction: The Dialectics of Cultural Hybridity' in Debating Cultural Hybridity, eds P. Webner \& T. Modood, Zed Books, London.

-2002, 'The Place which is Diaspora: Citizenship, Religion and Gender in the Making of Chaordic Transnationalism', Journal of Ethnic and Migration Studies, Jan vol. 28, i.1, 119-134.

Carta de Sydney and Informe de la Comision Cultural Politico-Social, Cabildos Culturales, 2002.

\section{List of interviews}

Interview a - 19.05.02, Canley Vale, N.S.W.

Interview b - 29.05.02, Fairfield, N.S.W.

Interview c - 01.08.02, Sydney City, N.S.W.

Interview d - 05.08.02, Strathfield, N.S.W.

Interview e - 15.08.02, Canterbury, N.S.W.

Interview f - 15.08.02, Canterbury, N.S.W.

Interview g - 29.05.08, Fairfield, N.S.W.

Interview $\mathrm{h}-12.08 .02$, via internet (to Canberra) 